\title{
SENARIO FATWA-FATWA ZAKAT DI MALAYSIA: PERSPEKTIF MAQASID SYARIAH
}

\section{Scenario of Fatwas on Zakat in Malaysia from the Perspective of Maqasid Sharia}

\author{
Azri Bhari * \\ Luqman Abdullah **
}

\begin{abstract}
The nature of Islamic legal practice in Malaysia is known for its adherence to the views of the Shafii school in fiqh issues based on the historical background of the arrival of Islam in Malaysia and the Islamic legal practice that have been adapted. Fatwas issued by the fatwa institution in Malaysia have evolved from time to time in accordance to the principles of Islamic law, which are flexible and accommodating to the changing environment. In recent years, developments in Islamic legal practice shows the ultimate determination of fatwas especially on zakat are no longer bound to the Shafii school. This shows an openness in considering the views of other mazhab/schools and the opinions of contemporary figh scholars in issuing laws or fatwas relating to zakat. This can be seen in the shift from the Shafii school to the views of other schoools and
\end{abstract}

\footnotetext{
* PhD Candidate at Department of Fiqh and Usul, Academy of Islamic Studies, University of Malaya, azrib178@salam.uitm.edu.my

** Senior Lecturer at Department of Fiqh and Usul, Academy of Islamic Studies, University of Malaya, luqmanabdullah@um.edu.my
} 
the opinion of contemporary figh scholars on fatwas. This article determines 26 out of 191 fatwas on zakat that have been classified into six themes have shifted from the Syafii school to others. The study also reviews the principles of maqasid sharia that hasve been deliberated in determining the fatwa on zakat. This qualitative study is conducted through library research and interviews. The data collected are analysed using inductive, deductive and comparative methods. The study shows a number of fatwas on zakat that have shifted from the Syafii school. Thus, it can be concluded that the Muftis and fatwa committees in Malaysia have strived to achieve the maqasid sharia from the maslahah and mafsadah perspectives in determining fatwas on zakat.

Keywords: Fatwa, Islamic Legal Practice, Syafii School, Maqasid Sharia, Malaysia

\section{PENDAHULUAN}

Pengaruh mazhab Syafii dalam institusi fatwa di Malaysia mempunyai hubungan rapat dengan sejarah kedatangan dan 
penyebaran Islam di negara ini ${ }^{1}$. Mazhab Syafii telah berkembang dan mendominasi proses penentuan hukum di negara ini sehingga menjadikan kedudukan mazhab Syafii berada di tingkat utama dalam semua aspek hukum, terutama dalam urusan berkaitan ibadat $^{2}$.

Undang-undang pentadbiran agama Islam di negerinegeri kecuali negeri Perlis, secara jelas memperuntukkan prosedur pengeluaran fatwa supaya rujukan fatwa dalam membuat keputusan hukum perlu bersandarkan kepada mazhab Syafii ${ }^{3}$. Peruntukan undang-undang tersebut jelas memberikan gambaran bahawa fatwa-fatwa zakat pada suatu ketika dahulu boleh dikatakan terikat dan didominasi dengan pandangan hukum fiqh daripada mazhab Syafii.

Abdullah Ishak, Islam di Nusantara (Khususnya di Tanah Melayu) (Kuala Lumpur: Bahagian Hal Ehwal Islam, Jabatan Perdana Menteri, 1992), 192.; Omar Awang, "The Major Arabic Sources Which Determined the Structure of Islamic Thought in the Malay Archipelago Before the Nineteenth Century A.D. in the Field of Law, Theology and Sufism," dalam Islamika, ed. Lutpi Ibrahim (Kuala Lumpur: Sarjana Enterprise, 1981), 82.; Abdul Halim ElMuhammady, Pengaruh Madhhab Shafi 'i dan Masalah Kaum Muda di Malaysia (Kajang: Persatuan Bekas Mahasiswa Islam Timur Tengah, 1982); ;.W. Arnold, The Preaching of Islam (London: t.p., 1913), 363-364.; Othman Ishak, Fatwa dalam Perundangan Islam (Kuala Lumpur: Penerbit Fajar Bakti Sdn. Bhd., 1981), 26.; Hasnan Kasan, Institusi Fatwa di Malaysia (Selangor: Penerbit Universiti Kebangsaan Malaysia, 2008), 12.; S.Q. Fatimi, Islam Come to Malaysia (Singapura: Sociology Research Institute, 1963), 6.; John Crawfurd, History of the Indian Archipelago (London: Frank Cass and Co. Ltd., 1877), 3: 77.

2 Anisah Ab. Ghani et al., "Penerimaan Masyarakat Islam di Malaysia Terhadap Amalan Percampuran Mazhab dalam Isu-isu Mazhab," Jurnal Fiqh 4 (2007), 198.; Noor Naemah Abd. Rahman, "Amalan Fatwa di Malaysia: Antara Keterikatan Mazhab dan Keperluan Tarjih," Jurnal Fiqh 4 (2007), 85-86.

3 Ahmad Hidayat Buang. "Analisis Fatwa-fatwa Syariah di Malaysia," dalam Fatwa di Malaysia. (Kuala Lumpur: Jabatan Syariah dan Undang-undang APIUM, 2004), 166.; Luqman Abdullah dan Nina Jihatea, "Bermazhab dan Fanatik Mazhab: Satu Sorotan dalam Kerangka Amalan Bermazhab Syafi'i Masyarakat Melayu" Jurnal Fiqh 4 (2007), 109. 
Walau bagaimanapun, dari masa ke semasa terdapat perubahan dalam peruntukan undang-undang berkaitan prosedur pengeluaran fatwa yang membenarkan rujukan fatwa berdasarkan pandangan-pandangan mazhab fiqh yang lain ${ }^{4}$. Ini menunjukkan fatwa yang diputuskan oleh pihak berautoriti berusaha meraikan perubahan persekitaran dan perkembangan semasa yang berlaku selaras dengan pengambilkiraan maqasid shariah.

Penulisan kajian terdahulu banyak melihat perubahan fatwa dari aspek keterbukaan menerima pandangan mazhab fiqh yang lain, namun artikel ini cuba menjelaskan kesungguhan pihak berautoriti menentukan fatwa dengan mengambilkira maqasid shariah.

\section{SENARIO FATWA-FATWA ZAKAT DI MALAYSIA}

Pengurusan fatwa di Malaysia telah berkembang sesuai dengan peredaran masa dan perubahan persekitaran. Pembaharuan dalam proses dan prosedur pengeluaran fatwa serta keterbukaan dalam menerima rujukan fatwa telah mengubah senario pengeluaran fatwa termasuk fatwa yang berkaitan zakat. Fatwa-fatwa tersebut dikeluarkan bagi menjawab isu dan permasalahan semasa yang tidak dibincangkan di dalam fiqh klasik. Oleh yang demikian, kajian ini akan menjalankan analisis tentang statistik jumlah fatwa zakat di Malaysia yang telah diputuskan oleh Muzakarah Jawatankuasa Fatwa Majlis Kebangsaan Malaysia ${ }^{5}$ (MJFMK) dan Jawatankuasa-jawatankuasa Fatwa Negeri-negeri ${ }^{6}$ untuk melihat senario perkembangan fatwa-fatwa zakat di Malaysia. Fatwafatwa tersebut akan dianalisis daripada beberapa perspektif seperti proses, prosedur dan kaedah rujukan fatwa sama ada bersandarkan kepada pandangan mazhab Syafii atau menggunapakai pandangan selain daripada mazhab Syafii. Maklumat daripada keputusan analisis itu akan memberikan suatu gambaran bahawa terdapat

$4 \quad$ Noor Naemah Abdul Rahman, "Ruang Ijtihad dalam Amalan Fatwa di Malaysia," 21.

5 Muzakarah Jawatankuasa Fatwa Majlis Kebangsaan Malaysia adalah berperanan untuk menyelaraskan fatwa-fatwa di Malaysia.

6 Setiap negeri di Malaysia mempunyai jawatankuasa fatwa masingmasing. 
fatwa-fatwa zakat yang dominannya diputuskan bersandarkan kepada mazhab Syafii, dan terdapat juga beberapa fatwa-fatwa zakat yang sudah mula mengambilkira pandangan di luar kerangka mazhab Syafii.

\section{Statistik Fatwa Zakat di Malaysia}

Senario perkembangan fatwa-fatwa zakat di Malaysia dapat dilihat dengan lebih tepat melalui analisis fatwa-fatwa berkaitan zakat. Berdasarkan kajian yang telah dijalankan, terdapat sebanyak 191 fatwa berkenaan zakat telah diputuskan di Malaysia. Setelah dianalisis, sejumlah 164 fatwa zakat yang telah diputuskan oleh Jawatankuasa Fatwa Negeri-negeri di Malaysia bermula dari tahun 1965 sehingga 2014. Manakala jumlah fatwa zakat yang dikeluarkan oleh MJFMK adalah sebanyak 27 fatwa bermula dari tahun 1979 sehingga 2012. Berikut adalah jadual fatwa-fatwa zakat yang telah diputuskan oleh Jawatankuasa Fatwa Negerinegeri di Malaysia dan MJFMK.

Jadual 1: Jumlah Fatwa Zakat yang telah Diputuskan oleh Jawatankuasa Fatwa Negeri-negeri di Malaysia dan MJFMK

\begin{tabular}{|c|c|c|c|c|c|}
\hline \multirow[b]{2}{*}{ 氰 } & \multirow[b]{2}{*}{ Negeri } & \multirow[b]{2}{*}{ Tahun } & \multicolumn{2}{|c|}{ Pewartaan } & \multirow[b]{2}{*}{$\begin{array}{c}\text { Jumlah } \\
\text { Fatwa } \\
\text { Zakat }\end{array}$} \\
\hline & & & 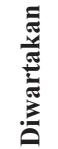 & 弟 & \\
\hline 1 & Perak & $1990-2011$ & 2 & 2 & 4 \\
\hline 2 & Johor & $2000-2013$ & 1 & 6 & 7 \\
\hline 3 & Kedah & $1965-2008$ & - & 8 & 8 \\
\hline 4 & Kelantan & $1990-2007$ & - & 10 & 10 \\
\hline 5 & Melaka & $2000-2014$ & 10 & 4 & 14 \\
\hline 6 & Negeri Sembilan & $1998-2014$ & 2 & 5 & 7 \\
\hline 7 & Pulau Pinang & $1976-2001$ & 1 & 7 & 8 \\
\hline 8 & Sarawak & $1996-2010$ & - & 7 & 7 \\
\hline 9 & Selangor & $1986-2009$ & 12 & 10 & 22 \\
\hline 10 & Terengganu & $1988-2010$ & - & 35 & 35 \\
\hline 11 & Wilayah Persekutuan & $1997-2014$ & 5 & 3 & 8 \\
\hline 12 & Perlis & $1988-1990$ & - & 5 & 5 \\
\hline 13 & Sabah & 2003 & 1 & - & 1 \\
\hline 14 & Pahang & 2012 & - & 1 & 1 \\
\hline 15 & MJFMK & $1979-2012$ & - & 27 & 27 \\
\hline & Jumlah & $1965-2014$ & 34 & 157 & 191 \\
\hline
\end{tabular}

Sumber: Pelbagai, Portal Rasmi Fatwa Malaysia ${ }^{7}$

7 Portal Rasmi Fatwa Malaysia, dicapai 18 Ogos 2014. 
Berdasarkan jadual di atas, negeri yang paling banyak mengeluarkan fatwa berkaitan zakat adalah Terengganu berjumlah 35 fatwa. Manakala negeri yang paling sedikit mengeluarkan fatwa berkaitan zakat adalah Pahang dan Sabah iaitu masing-masing 1 fatwa sahaja. Berkemungkinan faktor jumlah pengeluaran fatwa zakat banyak dan sedikit dipengaruhi oleh pertimbangan institusi fatwa sama ada perlu dikeluarkan sebagai fatwa atau hanya sebagai jawapan hukum semata-mata sahaja.

Fatwa zakat yang paling awal dikeluarkan adalah dari negeri Kedah sekitar tahun 1965. Seterusnya diikuti sepuluh tahun berikutnya pada sekitar tahun 1976 fatwa zakat dikesan dari Pulau Pinang. Berkemungkinan negeri kedah adalah negeri terawal mempunyai sistem catatan dan simpanan rekod yang baik berbanding negeri-negeri lain terhadap fatwa-fatwa yang diputuskan.

Fatwa-fatwa zakat di atas boleh dikategorikan sebagai fatwa yang diwartakan dan fatwa yang tidak diwartakan. Terdapat 34 fatwa zakat diwartakan yang telah diputuskan oleh Jawatankuasa Fatwa Negeri-negeri di Malaysia, manakala 157 fatwa zakat lagi tidak diwartakan merangkumi 27 fatwa zakat yang diputuskan oleh MJFMK dan 130 fatwa zakat yang diputuskan oleh Jawatankuasa Fatwa Negerinegeri di Malaysia.

\section{Analisis Teks Fatwa Zakat di Malaysia}

Keputusan fatwa-fatwa zakat yang diputuskan oleh Jawatankuasa Fatwa adalah bersifat ringkas dan kebanyakan tiada menyatakan sumber rujukan yang digunakan. Jika ada dinyatakan sumber rujukan sekalipun, hanya dalam bentuk keterangan yang ringkas sahaja. Dalam erti kata lain, fatwa-fatwa tersebut hanya berperanan untuk memberi khidmat penjelasan hukum kepada orang awam dan bukannya untuk disediakan bagi tujuan ilmiah dan akademik yang tinggi. Oleh yang demikian, keputusan fatwa tersebut dikeluarkan dalam format yang ringkas dan tidak disertakan sumber rujukan serta alasan yang berkaitan. Antara contoh fatwa tersebut adalah seperti berikut: 
Fatwa zakat pendapatan di negeri Selangor ${ }^{8}$ ialah:

Keputusan: Hukum zakat pendapatan adalah wajib ke atas umat Islam.

(1) Seтua umat Islam yang tinggal atau bekerja di Selangor hendaklah membayar zakat pendapatan kepada Pusat Zakat Selangor.

Fatwa pembayaran zakat fitrah menggunakan wang di Kedah ${ }^{9}$ ialah:

Keputusan: Mesyuarat Jawatankuasa Fatwa Negeri

Kedah yang bersidang pada 11 November 1989 telah membincangkan mengenai Pembayaran Zakat Fitrah Dengan Wang. Mesyuarat berpendapat adalah harus kaum muslimin di negeri ini mengeluarkan zakat fitrah yang wajib ke atas mereka dengan harga makanan yang biasa dimakan (beras).

Keterangan/Hujah: Taqlid kepada Mazhab Imam Abu Hanifah

Fatwa penolakan kos tanaman zakat padi di negeri Terengganu ${ }^{10}$ ialah:

Keputusan: Kewajipan zakat padi dikenakan setelah ditolak kos menanam, upah membajak tanah, harga baja, upah membaja serta upah menuai.

Fatwa pelantikan amil wanita oleh MJFMK ${ }^{11}$ ialah:

8 Portal Rasmi Fatwa Malaysia, e-Fatwa JAKIM, dicapai 6 Januari 2016, http://www.e-fatwa.gov.my/fatwa-negeri/fatwa-tentangzakat-pendapatan

9 Portal Rasmi Fatwa Malaysia, e-Fatwa JAKIM, dicapai 2 Februari 2016, http://www.e-fatwa.gov.my/fatwa-negeri/pembayaran-zakatfitrah-dengan-wang

10 Keputusan Fatwa Negeri Terengganu bagi Tahun 1999, dicapai 6 Januari 2016, http://mufti.terengganu.gov.my/maxc2020/portal/med ia/38/3b588319aa294496c924006279bc2886.pdf

11 Portal Rasmi Fatwa Malaysia, e-Fatwa JAKIM, dicapai 2 Februari 2016, http://www.e-fatwa.gov.my/fatwa-kebangsaan/wanita-danorang-bukan-islam-sebagai-amil-zakat-gaji-dan-pendapatan-dilembaga-hasi 
Wanita dan Orang Bukan Islam Sebagai Amil Zakat Gaji dan Pendapatan di Lembaga Hasil Dalam Negeri

Muzakarah Jawatankuasa Fatwa Majlis Kebangsaan Bagi Hal Ehwal Ugama Islam Malaysia Kali Ke-50 yang bersidang pada 10 Mei 2001 telah membincangkan Wanita Dan Orang Bukan Islam Sebagai Amil Zakat Gaji Dan Pendapatan Di Lembaga Hasil Dalam Negeri. Muzakarah telah memutuskan bahawa orang bukan Islam tidak boleh dilantik menjadi amil zakat dan wanita Islam boleh dilantik menjadi amil zakat gaji dan pendapatan di LHDN.

Selain itu, berdasarkan analisis terhadap keseluruhan teks fatwa-fatwa zakat yang telah dijalankan, majoriti daripada keputusan-keputusan fatwa zakat adalah bersandarkan kepada pandangan mazhab Syafii. Ini adalah selari dengan kajian yang dilakukan oleh Wan Zulkifli Wan Hasan ${ }^{12}$ dan Luqman Abdullah ${ }^{13}$ dalam mengkaji pengaruh mazhab Syafii pada fatwa-fatwa zakat.

Wan Zulkifli Wan Hassan ${ }^{14}$ telah memfokus fatwa-fatwa zakat yang dikeluarkan Jawatankuasa Fatwa Negeri Terengganu. Kajian ini bertujuan menganalisis pandangan mazhab Syafii yang digunakan dalam keputusan fatwa zakat berdasarkan sumber rujukan mazhab tersebut. Hasilnya mendapati pengaruh mazhab Syafii sangat dominan dalam sebahagian besar fatwa zakat yang diputuskan oleh Jawatankuasa Fatwa Negeri Terengganu. Berdasarkan kajian, hanya tiga fatwa daripada 104 keseluruhan fatwa zakat yang tidak bersandarkan kepada pandangan mazhab Syafii. Fatwa zakat yang tidak bersandarkan kepada pandangan

12 Wan Zulkifli Wan Hassan, "Pengaruh Mazhab Syafie dalam Fatwa Mengenai Zakat di Terengganu: Kajian dari Tahun 1953 - 2005" (tesis kedoktoran, Jabatan Fiqh dan Usul, Akademi Pengajian Islam, Universiti Malaya, 2008).

13 Luqman Abdullah, "Kedudukan Mazhab Syafi'i dalam Fatwa-fatwa Zakat di Malaysia: Sorotan Fatwa Muzakarah Jawatankuasa Fatwa Majlis Kebangsaan dari Tahun 2000-2010" Makalah, Seminar Isu-isu Kontemporari Dalam Mazhab Shafi'i, Pusat Penyelidikan Mazhab Shafi'i, Universiti Islam Sultan Sharif Ali (UNISSA) (Brunei, 2013), 139-155.

14 Wan Zulkifli Wan Hassan, "Pengaruh Mazhab Syafie dalam Fatwa Mengenai Zakat di Terengganu". 
mazhab Syafii adalah di atas pertimbangan mașlahah, tetapi tidak dijelaskan secara terperinci kerana bukan menjadi fokus kajian tersebut.

Manakala kajian yang dilakukan Luqman Abdullah ${ }^{15}$ dilihat hampir sama dengan hasil penulisan tesis Wan Zulkifli, namun berbeza skop fatwa yang dikaji. Kajian tersebut hanya memfokuskan kepada fatwa-fatwa zakat yang diputuskan oleh Muzakarah Jawatankuasa Fatwa Majlis Kebangsaan dari tahun 2000-2010. Kajian ini mendapati terdapat pengaruh mazhab Syafie dalam sebahagian besar fatwa zakat. Hanya sebilangan kecil sahaja iaitu empat fatwa zakat yang tidak bersandarkan kepada pandangan mazhab Syafii.

Terdapat juga beberapa fatwa diputuskan di luar kerangka mazhab Syafii. Antara pandangan di luar kerangka mazhab Syafii yang dijadikan sandaran keputusan fatwa-fatwa zakat di Malaysia ialah pandangan mazhab Hanafi dalam fatwa pengeluaran zakat fitrah dengan wang ${ }^{16}$ dan fatwa penolakan kos tanaman sebelum dikenakan zakat padi $^{17}$. Seterusnya adalah pandangan Yūsuf alQaraḍāwī dalam fatwa zakat gaji ${ }^{18}$ dan fatwa potongan zakat gaji ${ }^{19}$.

15 Luqman Abdullah, "Kedudukan Mazhab Syafi'i dalam Fatwa-fatwa Zakat di Malaysia," 139-155.

16 Jabatan Mufti Johor, Fatwa Mufti Kerajaan Johor yang Difatwakan oleh Dato'Syed Alwi bin Tohir al-Haddad, cet. ke-3 (Johor: Bahagian Penerbitan Jabatan Agama Johor, 1981), 1: 99-100.

17 Portal Rasmi Fatwa Malaysia, e-Fatwa JAKIM, dicapai 6 Januari 2016, http:/www.e-fatwa.gov.my/kategori-fatwa/zakat?page=5; Keputusan Fatwa Negeri Terengganu bagi Tahun 1999, dicapai 6 Januari 2016. http://mufti.terengganu.gov.my/maxc2020/portal/ media/38/3b588319aa 294496c924006279bc2886.pdf

18 Lihat "fatwa zakat gaji atau pendapatan," Portal Rasmi Fatwa Malaysia, e-Fatwa JAKIM, dicapai 6 Januari 2016, http://www.efatwa.gov.my/kategori-fatwa/zakat?page $=5$; Jabatan Perdana Menteri, Buku Fatwa-Fatwa Mufti Wilayah Persekutuan 19872010, 7.; Portal Rasmi Fatwa Malaysia, e-Fatwa JAKIM, dicapai 23 Januari 2016, http://www.e-fatwa.gov.my/fatwa-negeri/fatwatentang-zakat-pendapatan.

19 Portal Rasmi Fatwa Malaysia, e-Fatwa JAKIM, dicapai 6 Januari 2016, http://www.e-fatwa.gov.my/fatwa-negeri/fatwa-mengenaibayaran-zakat-gaji-bulanan-yang-dibuat-oleh-majikan-dengan-izinatau-per 
Dapatan analisis ini menunjukkan pihak berautoriti telah membuat keputusan fatwa di luar kerangka mazhab Syafii dalam beberapa isu dengan mengambilkira maqasid shariah. Walau bagaimanapun, MJFMK dan Jawatankuasa Fatwa Negeri-negeri di Malaysia masih terikat dengan pandangan mazhab Syafii dalam memutuskan keputusan fatwa-fatwa zakat.

\section{FATWA-FATWA ZAKAT DI LUAR KERANGKA MAZHAB SYAFII: ANALISIS PERSPEKTIF MAQASID SYARIAH}

Pembaharuan dalam proses dan prosedur pengeluaran fatwa serta perkembangan hukum telah mengubah senario pengeluaran fatwa termasuk fatwa yang berkaitan zakat. Fatwa-fatwa tersebut dilihat mengalami anjakan dan perubahan bagi tujuan penyesuaian dan memenuhi kemaslahatan masyarakat Islam. Perkembangan hukum yang dimaksudkan itu ialah penentuan fatwa berasaskan perubahan suasana dan persekitaran yang memerlukan pihak berautoriti mengambilkira pandangan diluar kerangka mazhab Shafii supaya mencapai maqasid syariah.. Kajian ini mengenal pasti 26 fatwa zakat yang telah diputuskan di luar kerangka mazhab Syafii daripada keseluruhan 191 fatwa zakat yang telah diklasifikasikan kepada enam tema disebabkan isu yang sama dan berulang. Berdasarkan analisis yang dijalankan, enam tema fatwa zakat tersebut ialah fatwa zakat gaji, fatwa potongan zakat gaji, fatwa penolakan kos tanaman sebelum pembayaran zakat padi, fatwa pembayaran zakat fitrah menggunakan wang, fatwa pelantikan amil wanita dan fatwa kaedah pembayaran zakat.

\section{Fatwa Zakat Gaji}

Keputusan fatwa zakat gaji dilihat telah diputuskan di luar kerangka mazhab Syafii. Penentuan fatwa zakat gaji dan pendapatan ini juga telah menunjukkan berlaku anjakan paradigma dalam amalan fatwa di Malaysia dengan mengambilkira pertimbangan maqasid syariah ${ }^{20}$. Di Malaysia, zakat gaji dan pendapatan mula dibincangkan pada sekitar tahun 1970an yang dirintis oleh Abdul

20 Wan Zulkifli Wan Hassan, "Pengaruh Mazhab Syafie dalam Fatwa Mengenai Zakat di Terengganu”, 225. 
Rashid Dail bersama sekumpulan penyelidik dari Universiti Kebangsaan Malaysia ${ }^{21}$.

Jadual 2: Fatwa-fatwa Zakat Gaji Mengikut Negeri di Malaysia

\begin{tabular}{|c|c|c|c|}
\hline$\dot{\bar{\oplus}}$ & Negeri & Tarikh Keputusan & Status \\
\hline 1 & W. Persekutuan & 09 April 1999 & Diwartakan pada 29 April 1999 \\
\hline 2 & Selangor & 16 Jan 2001 & Diwartakan pada 9 Mei 2002 \\
\hline 3 & Melaka & 22 Mei 2000 & Diwartakan \\
\hline 4 & Sarawak & 23 Nov 1996 & Tidak diwartakan \\
\hline 5 & Pulau Pinang & 26 April 2001 & Diwartakan pada 26 April 2001 \\
\hline \multirow{2}{*}{6} & \multirow{2}{*}{ Kelantan } & 12 Sept 1999 & Tidak diwartakan \\
\hline & & 16 Mac 1999 & Diwartakan pada 22 Julai 1999 \\
\hline 7 & Perak & 22 Mac 1990 & Diwartakan pada 16 Feb 2004 \\
\hline 8 & Johor & 17 April 2000 & Tidak diwartakan \\
\hline 9 & N.Sembilan & 8 Jun 1998 & Diwartakan pada 2 Julai 1998 \\
\hline \multirow{3}{*}{10} & \multirow{3}{*}{ MJFKM } & $\begin{array}{l}\text { Muzakarah } \\
\text { Kali Ke-31 dan } \\
\text { Muzakarah Khas } \\
\text { yang bersidang } \\
\text { pada 9 Dis } 1992 \\
\end{array}$ & Tidak diwartakan \\
\hline & & $\begin{array}{l}\text { Muzakarah Khas } \\
\text { pada } 22 \text { Jun } 1997\end{array}$ & Tidak diwartakan \\
\hline & & $\begin{array}{l}\text { Muzakarah Kali } \\
\text { Ke-56 pada } 7 \text { Mei } \\
2003\end{array}$ & Tidak diwartakan \\
\hline
\end{tabular}

Sumber: Fatwa Negeri dan MJFKM

Jadual di atas menunjukkan hampir keseluruhan negeri di Malaysia mengeluarkan fatwa zakat gaji. Secara praktis, zakat gaji telah pun dilaksanakan di seluruh Malaysia walaupun tidak dapat dikesan fatwa di negeri Sabah, Pahang, Kedah dan Perlis. Boleh dikatakan, sekitar tahun 1990an adalah kemuncak konsep zakat gaji dan pendapatan dapat diterima oleh masyarakat, bahkan mula dilaksanakan di Malaysia secara berperingkat-peringkat melalui fatwa yang diputuskan oleh jawatankuasa-jawatankuasa fatwa negeri.

21 Mujaini Tarimin, "Pelaksanaan Zakat Pendapatan dan Permasalahannya," dalam Zakat: Menuju Pengurusan Profesional (Kuala Lumpur: Utusan Publications \& Distributors Sdn Bhd, 2005), 19. 
Walau bagaimanapun, terdapat sedikit perbezaan keputusan fatwa zakat gaji di Malaysia iaitu fatwa negeri Perak menyatakan gaji adalah tidak wajib zakat kerana tidak menepati syarat hawl berdasarkan pandangan jumhur ${ }^{22}$. Manakala fatwa di negeri lain menyatakan wajib zakat gaji dengan mengambil pandangan alQaraḍāwī yang tidak mensyaratkan tempoh hawl terhadap zakat $m \bar{a} l$ al-mustafād. Sebaliknya wajib mengeluarkan zakat ini pada waktu memperolehinya ${ }^{23}$. Sementara itu, fatwa negeri Terengganu pula memberi pilihan sama ada menunggu syarat hawl atau tidak.

Pengeluaran zakat gaji dan pendapatan dilihat penting kerana kewajipan pengeluaran zakat dalam konteks ini akan memberi kebajikan dan kemaslahatan kepada masyarakat Islam. Sebaliknya jika zakat gaji dan pendapatan tidak diwajibkan, ini akan membawa kerugian kepada maqasid penambahan dana zakat untuk kepentingan umat Islam. Pengenaan zakat gaji dan pendapatan perlu diberi perhatian penting memandangkan kedudukan peranan zakat dilihat sebagai satu instrumen pembahagian harta di kalangan masyarakat yang memerlukan.

Para sarjana hukum bersetuju zakat harta pendapatan perlu ditunaikan demi kemaslahatan masyarakat Islam. Hal ini memandangkan gaji atau upah daripada pekerjaan yang dilakukan oleh seseorang mampu menjadikannya kaya dan berharta ${ }^{24}$. Gaji atau upah juga dilihat suatu bentuk kekayaan yang perlu dikenakan zakat selain daripada emas, perak, galian, hasil perniagaan, hasil ternakan dan sebagainya.

Dari perspektif maqāșid hifž al-māl, sekiranya zakat gaji dan pendapatan tidak dikenakan keadaan ini sudah tentu akan menyebabkan berlaku kepincangan dalam sistem sosial umat Islam. Orang yang bekerja dengan gaji yang lumayan akan terus melipatgandakan harta, manakala dana untuk membantu golongan fakir. miskin dan asnaf yang lain akan terus menyusut menyebabkan jurang antara kaya dan miskin semakin melebar.

22 Wahbah al-Zuhaylī, al-Fiqh al- Islāmī wa Adillatuh, cet. ke-2 (Dimasyq: Dār al-Fikr, 1985), 2:745-747.

23 Al-Qaraḍāwī, Fiqh al-Zakāh, 490.

24 Hamizul Abdul Hamid, Eksklusif Zakat (Selangor: Galeri Ilmu Sdn. Bhd., 2012), 49. 
Justeru itu, zakat berperanan untuk merapatkan jurang perbezaan tersebut.

\section{Fatwa Skim Potongan Zakat Gaji}

Pelaksanaan Skim Potongan Gaji (SPG) adalah suatu mekanisme pembayaran zakat gaji atau pendapatan secara ansuran bulanan melalui potongan dalam slip gaji yang telah dilaksanakan di Malaysia ${ }^{25}$. SPG memberi kemudahan kepada para majikan dan kakitangan kerajaan juga swasta untuk menunaikan tanggungjawab membayar zakat pendapatan secara mempercepatkan bayaran zakat sebelum tamat tempoh hawl atau dinamakan sebagai ta jijl al-zakāh ${ }^{26}$.

Isu hukum yang timbul dalam SPG ini ialah mempraktikkan ta 'jïl al-zakāh secara bertentangan dengan konsep yang sebenar ${ }^{27}$. Ta jīl al-zakāh yang dipraktikkan adalah sebelum jumlah pendapatan yang menjadi penentuan nisab benar-benar dimiliki oleh pekerja atau peserta SPG atau ta jīl dilaksanakan sebelum nisab dimiliki sepenuhnya ${ }^{28}$. Sebaliknya, konsep ta 'jül al-zakāh yang sebenar dalam perbincangan fiqh adalah merujuk kepada mempercepatkan pembayaran zakat sebelum tempoh hawl berlalu ke atas nisab yang telah sempurna ${ }^{29}$.

Suryani Masnan, dalam kajiannya menasihatkan walaupun pihak berautoriti di Malaysia menerima pandangan al-Qaraḍāwī yang melonggarkan syarat hawl dalam zakat al-māl al-mustafäd,

25 Portal Rasmi Majlis Agama Islam Johor, dicapai 18 Februari 2016, http://www.maij.gov.my/?page_id=157; Portal Rasmi Lembaga Zakat Selangor, dicapai 18 Februari 2016, http://www.zakatselangor. com.my/cara-bayaran/skim-berkat-skim-potongan-gaji/

26 Lihat fatwa bab 3, Portal Rasmi Fatwa Malaysia, e-Fatwa JAKIM, dicapai 6 Januari 2016, http://www.e-fatwa.gov.my/fatwa-negeri/ fatwa-mengenai-bayaran-zakat-gaji-bulanan-yang-dibuat-olehmajikan-dengan-izin-atau-per

27 Muhammad Ikhlas Rosele, Luqman Abdullah, Paizah Hj Ismail dan Mohd Anuar Ramli, "Konflik Fatwa di Malaysia: Satu Kajian Awal," Jurnal Fiqh 10 (2013), 40.

28 Secara amalannya, SPG ini telah dilaksanakan di seluruh Malaysia, walaupun fatwa berkaitan potongan zakat gaji tidak dikeluarkan oleh jawatankuasa fatwa negeri-negeri.

29 Wahbah al-Zuhaylī, al-Fiqh al-Islāmi wa Adillatuh, 755. 
tetapi perlu memastikan hanya pekerja yang mencapai paras nisab zakat sahaja yang membayar. Jika tidak, zakat tersebut tidak sah. Pengabaian hawl dalam memilih mempercepatkan bayaran zakat adalah diterima sebahagian mazhab dan zakat adalah sah, tetapi membayar zakat sebelum mencapai paras nisab adalah ditolak ${ }^{30}$.

Jadual 3: Fatwa Potongan Zakat Gaji

\begin{tabular}{|c|c|c|c|}
\hline Bil & Negeri & Tarikh Keputusan & Status \\
\hline 1 & Kelantan & 17 April 1995 & Tidak diwartakan \\
\hline
\end{tabular}

Sumber: Fatwa Negeri

Pelaksanaan SPG ini dilihat dapat mengurangkan rasa beban para pembayar pada setiap hujung tahun atau ketika sempurna tempoh hawl untuk membayar zakat dalam jumlah yang besar sekaligus. Potongan zakat daripada gaji bulanan dibuat bagi mengelakkan daripada menunggu lama untuk mengeluarkan zakat pada akhir hawl. Ini adalah suatu bentuk mașlahah dan kemudahan kepada para pembayar yang sudah pasti memiliki pendapatan tetap secara bulanan dalam tempoh setahun. Justeru itu, potongan zakat gaji secara bulanan dapat membantu para pembayar zakat mengurus kewangan melalui pembayaran awal zakat tanpa membelakangkan syarat hawl dan nisab yang perlu dipatuhi.

Seterusnya, maqasid mempercepatkan pembayaran zakat pendapatan supaya pembayar zakat tidak hilang kelayakan kerana kekurangan nisab di hujung tahun. Abd. Rashid dan Suryani juga turut menyatakan perkara yang sama tentang pembayaran zakat secara ta jīl dapat mengelakkan pembayar terkeluar daripada kelayakan membayar zakat pendapatan kerana berkemungkinan

30 Suryani Masnan, "Kaedah Pembayaran Zakat Pendapatan Melalui Skim Potongan Gaji oleh Lembaga Zakat Selangor" (Disertasi Sarjana, Jabatan Fiqh dan Usul, Akademi Pengajian Islam, Universiti Malaya, 2012), 116. 
hasil pendapatan telah dibelanjakan sehingga tidak berbaki cukup nisab pada penghujung tempoh $h a w l^{31}$.

Zakat merupakan satu ibadah yang berkait rapat dengan Allah, harta dan kepentingan manusia. Zakat lebih utama dibayar awal daripada menunggu waktu yang ditetapkan iaitu hawl sebagai syarat sah zakat, apatah lagi terhadap zakat al-māl al-mustafād yang lebih utama dibayar jika tidak disyaratkan hawl. Ini adalah mengambilkira pertimbangan mașlahah dengan dana zakat yang terkumpul awal tersebut dapat membantu masyarakat yang terdesak memerlukan berbanding dengan kutipan yang berada di hujung hawl. Selain itu, ia memudahkan zakat diagihkan kepada yang berhak secara bulanan. Seterusnya, maqasid di sebalik SPG ini juga adalah tertunai dan terlaksana kewajipan berzakat di kalangan pekerja yang mempunyai pendapatan tetap.

\section{Fatwa Penolakan Kos Tanaman ke atas Zakat Padi}

Pada asasnya, fatwa yang diputuskan oleh jawatankuasa fatwa negeri-negeri di Malaysia adalah berdasarkan kepada pandangan mazhab Syafii yang mewajibkan zakat dikeluarkan daripada hasil kasar yang diperolehi tanpa perlu menolak kos operasi tanaman dan kos sara hidup. Namun jika dilihat pada hari ini, terdapat fatwa baru yang diputuskan semula di luar kerangka mazhab Syafii yang dilihat selari dengan pandangan mazhab Hanafi yang membenarkan penolakan semua kos yang ditanggung oleh para petani. Walau bagaimanapun masih terdapat beberapa negeri yang masih mengekalkan fatwa asal yang berasaskan kepada pandangan mazhab Syafii dalam isu penolakan kos ini.

Majoriti sarjana hukum fiqh berpendapat bahawa kos operasi tanaman mestilah ditanggung oleh para petani dan nisab zakat dikira apabila mereka memperoleh hasil tanaman dan tidak perlu menolak kos operasi tanaman apabila hendak mengeluarkan

$31 \quad$ Abd. Rashid Dail, "Zakat Gaji dan Pendapatan Bebas: Satu Analisa Tentang Strukturnya," 9.; Suryani Masnan, "Kaedah Taksiran Zakat Pendapatan Menurut al-Qaradawi: Kajian Perbandingan dengan Skim Potongan Gaji (SPG)," dalam Pengurusan Zakat Kontemporari (Melaka: IKaZ UiTM Melaka, 2013). 
zakat $^{32}$. Kos operasi tanaman tidak perlu ditolak terlebih dahulu kerana tiada nas yang menyatakan perlu menolak kos operasi tanaman. Nas yang ada hanyalah menerangkan kadar pengeluaran zakat sebanyak lima peratus atau sepuluh peratus berdasarkan kaedah pengairan yang digunakan oleh para petani sama ada tanaman yang menggunakan pengairan semula jadi atau pengairan yang menggunakan tenaga buruh ${ }^{33}$.

Manakala sarjana hukum fiqh yang berpandangan zakat pertanian perlu dikenakan tolakan kos operasi tanaman sebelum ditunaikan zakat ialah Ibn 'Arabī, Abū 'Ubayd, al-Qaraḍāwī, 'Ațiyyah dan Syahațah ${ }^{34}$. Pandangan ini selari dengan athar yang diriwayatkan oleh Jābir bin Zayd bahawa Ibn 'Umar r.a. dan Ibn 'Abbās r.a. yang membenarkan penolakan hutang atau perbelanjaan terhadap pertanian, kemudian lebihan daripada hasil pertanian barulah dikeluarkan zakat ${ }^{35}$.

Jadual 4: Fatwa-fatwa Penolakan Kos Tanaman Zakat Padi

\begin{tabular}{|c|l|l|l|l|}
\hline Bil. & \multicolumn{1}{|c|}{ Negeri } & \multicolumn{1}{|c|}{ Tarikh Keputusan } & Status & Keputusan \\
\hline 1 & Kedah & 13 Oktober 1996 & Tidak diwartakan & Tolak kos \\
\hline 2 & Kelantan & 12 Sept 1999 & Tidak diwartakan & Tolak kos \\
\hline 3 & Terengganu & 21 November 1999 & Tidak diwartakan & Tolak kos \\
\hline 4 & Perlis & 4-5 Mei 2014 & Tidak diwartakan & Tolak kos \\
\hline
\end{tabular}

Sumber: Fatwa Negeri

Jadual di atas menunjukkan fatwa dari empat buah negeri membenarkan penolakan kos tanaman dikira terlebih dahulu sebelum dikenakan zakat padi kepada petani. Boleh dikatakan negeri yang mengeluarkan fatwa tersebut adalah tempat yang banyak melakukan aktiviti penanaman padi secara meluas. Oleh sebab itu, fatwa dikeluarkan bagi mempertimbangkan kemaslahatan para petani.

Isu kewajaran penolakan kos tertentu sebelum diwajibkan zakat tanaman sering dibahaskan kerana dilihat bersifat semasa dan

32 Ibn Hazm, al-Muhallā, 286-287.; Wahbah al-Zuhaylī, al-Fiqh alIslāmī wa Adillatuh, 810.

33 Ibn Hazm, al-Muhallā, 286-287.; Wahbah al-Zuhaylī, al-Fiqh alIslāmī wa Adillatuh, 810.

34 Al-Qaraḍ̄āī, Fiqh al-Zakāh, 404. Abī 'Ubayd al-Qāṣim bin Sālam, Kitāb al-Amwāl (Bayrūt: Dār al-Fikr, 1988), 611.

35 Abī 'Ubayd, Kitāb al-Amwāl, 611. 
dalam usaha menepati kehendak maqasid syariah. Penolakan kos operasi tanaman perlu dilakukan kerana dilihat banyak bebanan yang ditanggung oleh para petani dalam mengusahakan tanaman padi. Para petani terpaksa menggunakan kos yang tinggi untuk jentera membajak, upah, baja dan racun kawal penyakit serta binatang perosak. Pelepasan kos operasi tanaman padi adalah demi mașlaḥah para petani dan bagi tujuan mencapai maqasid zakat ${ }^{36}$.

Al-Qaraḍāwī dalam mengemukakan rasional keperluan penolakan kos operasi tanaman terlebih dahulu adalah berdasarkan kepada maqasid syariah, antaranya ialah pertama, bebanan dan kos merupakan faktor yang memberi kesan dalam hukum. Kadar pengeluaran zakat berbeza disebabkan adanya bebanan dan kos. Contohnya, bagi pengairan yang memerlukan peralatan atau tenaga manusia kadar pengeluaran zakat ialah lima peratus sahaja. Begitu juga dengan zakat binatang ternakan, sekiranya penternak perlu mencari makanan untuk binatang ternakannya sepanjang tahun, maka binatang ternakan tersebut tidak dikenakan zakat ternakan. Jika diqiyaskan perkara ini dengan zakat padi, maka wajarlah kos operasi tanaman itu tidak dikenakan zakat ${ }^{37}$. Kedua, zakat diwajibkan kerana adanya pertumbuhan. Hakikat kesuburan ialah pertambahan. Ini bermaksud kesuburan pada harta berkenaan tidak dianggap berlaku jika kos penyuburan sama banyak atau lebih daripada penghasilan ${ }^{38}$.

Pandangan al-Qaraḍāwī ini disokong oleh Syahațah dan 'Ațiyyah yang berpandangan kos operasi tanaman terkait secara langsung dengan pertanian. Misalnya, kos pembelian bahan kimia (racun dan baja), upah (tenaga kerja dan penghantaran), biji benih, bayaran sewa tanah, cukai dan perbelanjaan pemulihan

36 Ummi Farahin Yasin, Noor Naemah Abdul Rahman dan Mohd Faez Mohd Shah, "Pengambilkiraan Realiti Semasa dalam Berfatwa: Analisis Terhadap Fatwa Zakat di Selangor," Jurnal Fiqh 10 (2013), 103.

37 Al-Qaraḍāwī, Fiqh al-Zakāh, 404.

38 Al-Qaraḍāwī, Fiqh al-Zakāh, 404. 
$\operatorname{tanah}^{39}$. Dalam menyatakan pandangan berhubung kos operasi tanaman ini, Syahațah bersandarkan ketetapan yang dibuat oleh al-Hay'ah al-Syar 'iyyah al-'Alamiyyah li al-Zakāh bahawa kos yang dibenarkan untuk tolakan itu adalah kos yang ada kaitan dengan perbelanjaan pertanian, tanpa membenarkan penolakan perbelanjaan yang tiada kaitan dengan pertanian ${ }^{40}$.

Isu penolakan kos operasi tanaman juga dilihat berkait rapat dengan isu penetapan kadar zakat tanaman kerana melibatkan perbincangan kaedah "pengairan" dan "usaha" yang ditanggung oleh para petani sehinggakan kadar zakat pertanian dikurangkan sebanyak lima peratus. 'Illah yang boleh diperhatikan adalah beban yang ditanggung oleh para petani. Jika dahulu penggunaan kos hanya melibatkan pengairan sahaja, bersesuaian dengan keadaan dan tempat ketika itu yang tidak melibatkan teknologi moden dan kos yang terlalu tinggi seperti hari ini.

Oleh itu, adalah menepati kehendak maqasid syariah mengkaji kos-kos yang ditanggung para petani masa kini kerana penolakan terhadap bentuk kos pengairan pada waktu duhulu adalah realiti tanggungan kos ketika itu. Di Malaysia, bebanan tidak terhad kepada kaedah pengairan sahaja akan tetapi termasuk juga kos pengeluaran yang ditanggung oleh para petani seperti kos bahan input, kos operasi tanaman yang melibatkan jentera moden dan modal yang tinggi serta kos sara hidup petani.

Dari aspek kewajaran penolakan kos-kos sara diri petani dan tanggungan mereka termasuklah makanan, minuman, pakaian, tempat tinggal dan pendidikan merupakan keperluan darūriyyat demi kelangsungan kebahagiaan sesebuah keluarga sepatutnya diambilkira sebagai pelepasan had kifayah sepertimana penolakan dalam zakat pendapatan. Namun, penolakan kos sara hidup dibenarkan dengan syarat seseorang petani hanya bergantung

39 Syahațah, Husayn, al-Tațbiq al-Mu'āṣir li al-Zakāh wa Kayfa Tahsib Zakāh Mālik (Miṣr: Dār al-Nasyr li al-Jāmi'at, 2000), 139.; Muḥammad Kamāl 'Ațiyyah, Hāll al-Tațbiqiyyah fì Muhāsabāt al-Zakāh: Perakaunan Zakat Teori dan Praktis, terj. Muhammad Kamal 'Atiyyah (Kuala Lumpur: Dewan Bahasa dan Pustaka, 1995), 28.

40 Syahatah, al-Tațbiq al-Mu'ạșir li al-Zakāh, 139. 
kepada sumber pendapatan hasil daripada penanaman padi dan tidak memiliki sumber pendapatan yang lain.

\section{Fatwa Pembayaran Zakat Fitrah Menggunakan Wang}

Amalan pelaksanaan zakat fitrah di Malaysia ditunaikan dengan nilai mata wang bagi menggantikan satu gantang beras bagi setiap orang Islam telah diputuskan oleh Jawatankuasa Fatwa NegeriNegeri. Fatwa ini telah diputuskan di luar kerangka mazhab Syafii yang membolehkan pembayaran zakat fitrah dengan menggunakan wang dan bukan dengan makanan asasi penduduk tempatan. Fatwa yang membolehkan pembayaran zakat fitrah dengan menggunakan wang adalah selari dengan pandangan daripada mazhab Hanafi.

Jadual 5: Fatwa-fatwa Pembayaran Zakat Fitrah Menggunakan Wang

\begin{tabular}{|c|l|l|l|}
\hline Bil. & \multicolumn{1}{|c|}{ Negeri } & Tarikh Keputusan & \multicolumn{1}{c|}{ Status } \\
\hline 1 & Kedah & 11 November 1989 & Tidak diwartakan \\
\hline 2 & N.Sembilan & 7 Oktober 2002 & Diwartakan pada 21 Nov 2002 \\
\hline 3 & Perak & 8 Julai 2004 & Tidak diwartakan \\
\hline 4 & Melaka & 11 September 2008 & Tidak diwartakan \\
\hline 5 & Selangor & 18 Mac 2009 & Diwartakan pada 30 Julai 2009 \\
\hline
\end{tabular}

Sumber: Fatwa Negeri

Jadual di atas menunjukkan fatwa pembayaran zakat fitrah dengan menggunakan wang sebagai ganti kepada beras bermula seawal tahun 1989 di negeri Kedah. Fatwa-fatwa yang dikeluarkan hampir sama dengan menyatakan beras sebagai kayu ukur zakat fitrah dan pembayaran dengan nilai harga beras dalam Ringgit Malaysia.

Al-Qaraḍāwī dan Muhammad 'Uqlah menjelaskan sebab utama perbezaan pandangan sarjana hukum fiqh ialah berpunca daripada perbezaan pandangan tentang hakikat zakat. Adakah zakat merupakan ibadah dan semata-mata pengabdian kepada Allah SWT atau merupakan kewajipan terhadap harta orang kaya untuk golongan miskin dengan maksud lain cukai harta yang diwajibkan ke atas pemilik nisab ${ }^{41}$.

Beliau mengulas lanjut, sebenarnya zakat meliputi dua hakikat tersebut iaitu ibadah dan kewajipan harta. Namun, Imam Syafii,

41 Al-Qaraḍāwī, Fiqh al-Zakāh, 811. 
Imam Ahmad, sebahagian ulama Maliki dan ulama mazhab Zāhirī mengangkat makna ibadah dan pengabdian kepada Allah SWT ke atas zakat. Oleh sebab itu, mereka mewajibkan untuk mengeluarkan zat seperti yang disebut dalam nas. Sebaliknya Imam Abu Hanifah mengangkat makna kewajipan harta yang bertujuan memenuhi keperluan golongan miskin, maka diharuskan menggunakan nilai harga $^{42}$.

Menurut al-Kāsan̄i, kewajipan mengeluarkan makanan yang dinaskan sebagai zakat ialah berasaskan ianya harta yang bernilai secara umum dan bukan berasaskan hakikat bahawa ia adalah jenis atau bahan tertentu. Oleh sebab itu, zakat boleh dibayar dengan harga bahan-bahan berkenaan, sama ada dalam bentuk mata wang atau barangan atau apa sahaja ${ }^{43}$.

Al-Kasānī juga mengulas pada hakikatnya yang wajib ialah "mencukupkan" kedudukan fakir dan miskin. Oleh sebab itu, usaha mencukupkan golongan fakir dan miskin boleh dilakukan dengan membayar nilai harga. Malah pembayaran nilai harga lebih berkesan dalam memenuhi keperluan kehidupan golongan tersebut. Justeru itu, jelaslah bahawa nas yang menyebut bahanbahan makanan berkenaan adalah berasaskan kepada konsep "mencukupkan" ". Hal ini adalah selaras dengan sabda Nabi SAW yang bermaksud 'cukupkan mereka daripada meminta seperti hari ini' $^{\prime 4}$.

Mahmood Zuhdi mengulas huraian yang dibuat oleh alKasānī ini menarik sekali dan wajar diterima. Agak jelas sekali apabila Nabi SAW menyebut bahawa bahan-bahan seperti itu, pertimbangannya ialah bahawa ia boleh memberi halangan kepada fakir miskin memandangkan sifatnya sebagai bahan utama dalam keperluan hidup. Maka sekiranya harga bahan-bahan seperti itu boleh memainkan peranan yang sama, mengapa tidak

Al-Qaraḍāwī, Fiqh al-Zakāh, 811-812.

43 'Alā' al-Dīn Abī Bakr bin Mas ‘ūd al-Hanāfĩ al-Kasānī, Badā'i ‘ alȘana 'i', cet. ke-2 (Bayrūt: Dār al-Kutub al-'Ilmiyyah 2003), 2:543.

44 Al-Kasān̄i, Badā'i ‘ al-Sana’i’, 2:543.

45 Ab̄̄ Bakar Aḥmad bin al-Husayn bin 'Al̄̄ al-Bayhaq̄î, al-Minnatu al-Kubrā Syarh wa Takhrīj Sunan al-Șughrā, ed. Muhammad Dīā' al-Raḥmān al- 'Aẓmī, Kitāb al-Zakāh, no. hadīth 1280 (Rīyāụ: Maktabah āl-Rusyd, 2001), 221. 
ia dibenarkan sahaja mengambil tempat. Malah pada hari ini mata wang lebih berkesan fungsinya dalam melegakan hidup seseorang berbanding dengan bahan makanan. Berdasarkan pandangan Abū Hanifah ini, pembayaran dalam bentuk mata wang bukan sahaja boleh pada masa ini tetapi lebih baik ${ }^{46}$.

Pertimbangan mașlahah untuk asnaf yang diambilkira dalam pembayaran zakat fitrah menggunakan wang ialah lebih memudahkan dan bermanfaat terutamanya kepada asnaf fakir dan miskin. Penerimaan wang lebih bermakna dan memudahkan bagi golongan tersebut untuk mendapatkan atau membeli sesuatu keperluan lain berbanding makanan utama iaitu beras yang merupakan sebahagian daripada keperluan sahaja.

Tambahan pula di zaman sekarang, semua urusan transaksi jual beli adalah dengan perantaraan wang, berbanding suatu ketika dahulu menggunakan sistem barter dalam aktiviti ekonomi untuk mendapatkan barang. Justeru itu, pandangan mengeluarkan zakat fitrah dengan wang adalah lebih sesuai dan menepati maqasid pensyariatan zakat bagi membantu memudahkan para asnaf zakat.

Seterusnya, pertimbangan yang diambilkira jika zakat fitrah dikeluarkan dengan beras akan menyebabkan pihak pengurusan zakat pula terpaksa menanggung kos yang besar dalam menjalankan kutipan. Sekiranya amil menerima beras sebagai zakat fitrah, sudah tentu memerlukan kenderaan untuk mengangkat beras tersebut dalam kuantiti yang sangat banyak dan berat. Keadaan ini menyebabkan mașlahah penjimatan kos pengangkutan perlu diambilkira dan dikurangkan berbanding menggunakan wang sebagasi ganti kepada beras.

\section{Fatwa Pelantikan Amil Wanita}

Hukum berkaitan amil zakat timbul apabila terdapat wanita yang dilantik menjadi amil, sedangkan pengamalan dalam mazhab Syafie melarang pelantikan amil dari kalangan wanita dan tidak pernah timbul dalam sejarah dahulu wanita menjadi amil zakat. Namun, dalam perkara ini fatwa memutuskan pelantikan amil

46 Mahmood Zuhdi Abd. Majid, Pengurusan Zakat, 395. 
di kalangan wanita yang dilihat dapat membantu melicinkan pentadbiran dan pengurusan zakat.

Jadual 6: Fatwa-fatwa Pelantikan Amil Wanita

\begin{tabular}{|c|c|c|c|}
\hline Bil & Negeri & Tarikh Keputusan & Status \\
\hline 1 & MJFMK kali ke-50 & 10 Mei 2001 & Tidak diwartakan \\
\hline
\end{tabular}

Sumber: Fatwa MJFKM

Golongan yang membenarkan wanita dilantik menjadi amil zakat menyatakan bahawa tidak terdapat dalam pengamalan Nabi SAW dan para Sahabat terdahulu, tidak memberi maksud atas pengharaman. Hal ini disebabkan soal kutipan wang zakat, bukanlah perkara ibadat secara khusus yang memerlukan kepada nas yang șahīh dan șarīh, tetapi tertakluk kepada pertimbangan mașlahah. Oleh itu, larangan atas alasan tidak pernah berlaku pada zaman Nabi SAW dan para Sahabat adalah tidak tepat ${ }^{47}$.

Dalam isu pelantikan wanita menjadi amil zakat, al-Qaraḍāwī mengulas bahawa tidak terdapat dalil khusus melarang wanita menjadi pengurus zakat. Walau bagaimanapun, kaedah umum dalam syariat Islam yang mewajibkan wanita hidup lebih waspada dan tidak bercampur lelaki kecuali perlu, menjadikan lelaki lebih utama menjawat jawatan seperti itu daripada melakukan urusan zakat yang lebih banyak berhubung dengan kaum wanita sendiri, seperti membahagi-bahagikan zakat di kalangan kaum wanita sendiri dan sebagainya. Jelaslah, isunya bukan soal kepimpinan tetapi soal pergaulan. Oleh kerana itu, ia tertakluk kepada hukum pergaulan itu sendiri dalam Islam ${ }^{48}$.

Maqasid pelantikan amil di kalangan wanita dilihat dapat memelihara pergaulan antara lelaki dan perempuan agar terhindar daripada fitnah. Urusan kutipan dan agihan zakat dapat dijalankan dengan lebih selesa dan aman di kalangan kaum wanita sahaja. Adalah wajar sekiranya wanita disantuni dan dilayan oleh kaumnya sendiri. Oleh sebab itu, pelantikan sebagai amil dibenarkan atas pertimbangan mașlahah demi keselesaan dan penjagaan maruah kaum wanita itu sendiri.

47 'Umar Sulaymān al-Asyqar, "Idārah Wāl̄̄ Māl al-Zakāh aw Mașraf al- 'Amilīn 'Alayhā,” dalam Abhāth Qad̄àyā al-Zakāh al-Mu 'āṣarah, cet. ke-3 (al-Urdun: Dār al-Nafā' is, 2004), 2:741. Al-Qaraḍ̄̄ī, Fiqh al-Zakāh, 600. 
Selain itu, pelantikan wanita sebagai amil dilihat boleh menarik lebih ramai lagi pembayar zakat di kalangan kaum wanita itu sendiri. Pada masa kini, khususnya kaum wanita di Malaysia ramai yang berkerjaya dan menjadi hartawan hasil daripada pendapatan bekerja dan perniagaan. Justeru itu, atas dasar pertimbangan mașlahah amil wanita lebih sesuai dan berkesan mendekati kaum wanita untuk memberi galakan dan khidmat perundingan pembayaran zakat. Hal ini dilihat menepati kehendak maqasid shariah dalam membantu meningkatkan jumlah kutipan dana zakat untuk diagihkan kepada golongan asnaf. Secara tidak langsung dapat meningkatkan kutipan dana zakat untuk keperluan para asnaf.

\section{Fatwa-Fatwa Kaedah Pembayaran Zakat Melalui Perkhidmatan Perbankan Internet Online, SMS, Mesin ATM Dan Kad Kredit di Malaysia}

Secara tradisi dan amalan di Malaysia, pembayaran zakat dilakukan dengan cara pertemuan antara pembayar zakat dan amil yang bertanggungjawab mengutip zakat daripada pihak institusi-institusi zakat. Pada masa kini, wujudnya kecenderungan masyarakat di Malaysia untuk menggunakan perkhidmatan 
perbankan internet online ${ }^{49}, \mathrm{SMS}^{50}$, mesin $\mathrm{ATM}^{51}$ dan kad kredit ${ }^{52}$ yang boleh membawa kemudahan dalam urusan seharian ${ }^{53}$. Penggunaan teknologi yang meluas turut memberi kesan kepada hukum-hakam ibadah yang berkaitan termasuk juga ibadah zakat ${ }^{54}$.

49 Internet sebagai sebuah jaringan maklumat antarabangsa. Ia adalah satu kumpulan jaringan komputer yang bersambung antara satu sama lain. Ahmad Rayyan, Khidmat al-Internet (Emirates: Manshurat alMajma' al-Thaqafi Abu Zabi, 1997), 19.

50 SMS ialah perkhidmatan yang membolehkan penghantaran atau penerimaan mesej alfanumerik dari telefon bimbit, alamat e-mel atau menerusi laluan mesej SMS awam atau swasta pada internet. Ardit Llazani, "An SMS Client for Mobile Banking" (Disertasi M.Sc., Fakulti Sains Komputer \& Teknologi Maklumat, Universiti Malaya, 2003), 16.; Sistem SMS (Short Messaging System) atau Sistem Pesanan Ringkas adalah manefestasi rangkaian teknologi telekomunikasi generasi ke-2 (2G) berasaskan standard GSM (Global System for Mobile Communication). Teknologi 2G ini pada dekad 1990an. Ia memanfaatkan konsep cellular dalam jaringan GSM ini. Lihat Gwenael Le Bodic, Mobile Mesaging Technologies and Services: SMS, EMS and MMS (New York: John Wiley \& Sons Inc, 2005).

51 Mesin juruwang automatik (ATM) merupakan sejenis peranti telekomunikasi berkomputer yang menyediakan capaian transaksi kewangan kepada pelanggan institusi kewangan di kawasan tumpuan awam tanpa memerlukan juruwang manusia atau kerani bank. Lihat, Laman Web Wikipedia, dicapai 27 Februari 2016, https://ms.wikipedia.org/wiki/Mesin juruwang_automatik.

52 Kad kredit merupakan satu kaedah pembayaran yang membolehkan anda membeli barangan atau mendapatkan perkhidmatan tanpa menggunakan wang tunai. Apabila anda menggunakan kredit kad, pengeluar kad kredit akan membayar terlebih dahulu bagi pihak anda dan kemudiannya menghantar bil kepada anda dalam bentuk penyata bulanan. Lihat Laman Web Info Perbankan, dicapai 27 Februari 2016, http://www.bankinginfo.com.my/02_know_your_ products/0206 things to note/credit_cards.php?intPrefLangID $=2$.

53 Ummi Farahin Yasin, Noor Naemah Äbdul Rahman dan Mohd Faez Mohd Shah, "Pengambilkiraan Realiti Semasa dalam Berfatwa".

54 Muhammad Fakhruddin Ishak, "Kesan Teknologi Moden Terhadap Perubahan Hukum: Analisis Terhadap Penggunaan Short Message Service (SMS)" (Disertasi Sarjana, Kuala Lumpur: Akademi Pengajian Islam Universiti Malaya, 2010), 68. 
Senario Fatwa-fatwa Zakat di Malaysia: Perspektif Maqasid Syariah

Jadual 7: Fatwa-fatwa Kaedah Pembayaran Zakat

\begin{tabular}{|c|c|c|c|c|}
\hline 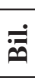 & Fatwa & Negeri & $\begin{array}{c}\text { Tarikh } \\
\text { Keputusan }\end{array}$ & Status \\
\hline \multirow{5}{*}{1} & \multirow{5}{*}{$\begin{array}{l}\text { Pembayaran } \\
\text { zakat melalui } \\
\text { SMS }\end{array}$} & \multirow{3}{*}{ Melaka } & 26 Jun 2014 & Tidak diwartakan \\
\hline & & & 25 Feb 2011 & $\begin{array}{l}\text { Diwartakan pada } \\
29 \text { Sept } 2011\end{array}$ \\
\hline & & & 11 Sept 2008 & $\begin{array}{l}\text { Diwartakan pada } \\
19 \text { Nov } 2009 \\
\end{array}$ \\
\hline & & Terengganu & 20 Sept 2006 & Tidak diwartakan \\
\hline & & Negeri Sembilan & 5 Ogos 2009 & Tidak diwartakan \\
\hline \multirow{2}{*}{2} & \multirow{2}{*}{$\begin{array}{l}\text { Pembayaran } \\
\text { zakat melalui } \\
\text { kad kredit }\end{array}$} & \multirow{2}{*}{ Melaka } & 18 Dis 2008 & $\begin{array}{l}\text { Diwartakan pada } \\
19 \text { Nov } 2009\end{array}$ \\
\hline & & & 26 Feb 2014 & $\begin{array}{l}\text { Diwartakan pada } \\
26 \text { Feb } 2014\end{array}$ \\
\hline 3 & $\begin{array}{l}\text { Pembayaran } \\
\text { zakat melalui } \\
\text { internet banking } \\
\text { online }\end{array}$ & Selangor & 16 Jan 2001 & Tidak diwartakan \\
\hline
\end{tabular}

Sumber: Fatwa Negeri

Jadual di atas memnunjukkan fatwa pembayaran zakat melalui perkhidmatan perbankan internet online, SMS, mesin ATM dan kad kredit merupakan suatu perkara baru yang belum pernah berlaku dan dibincangkan hukum berkaitannya oleh sarjana hukum fiqh pada masa lalu. Pembayaran zakat melalui kaedahkaedah tersebut telah menggambarkan suatu inovasi kaedah pembayaran zakat telah berkembang dari pertemuan secara fizikal antara pembayar dengan amil sehinggalah menjadi pertemuan secara maya sahaja ${ }^{55}$.

Pembayaran zakat dinilai sah di sisi syariat apabila berlaku dua perkara, iaitu niat berzakat dan berlaku pemindahan harta zakat. Berkaitan isu pembayaran zakat menerusi medium seperti yang dinyatakan di atas, dilihat niat sudah berlaku dan pemindahan wang juga turut telah berlaku. Justeru itu, hukum pembayaran zakat adalah sah melalui medium berkenaan.

Niat merupakan perkara yang disepakati oleh para ulama sebagai sesuatu yang wajib dalam pengeluaran zakat dan tidak sah

55 Hamizul Abdul Hamid, Zakat Terapi Kekayaan (Selangor: Grup Buku Karangkraf, 2011), 246. 
zakat tanpa niat ${ }^{56}$. Dalam kaedah pembayaran secara elektronik ini, penyertaan niat sewaktu pembayaran zakat dilakukan tidak menjadi masalah. Ini kerana setiap pembayar sudah semestinya akan menyertakan niat untuk membayar zakat sewaktu mengesahkan transaksi yang menunjukkan bahawa ia bersetuju untuk membayar zakat. Imam Syafii menegaskan niat yang dilafazkan tidak menjadi syarat terhadap sahnya pembayaran zakat $^{57}$.

Berhubung isu akad iaitu ijab dan qabul ketika pembayaran zakat adalah tidak diperlukan dan tidak tidak memberi kesan terhadap sahnya pembayaran zakat yang dilakukan. Walau bagaimanapun, terdapat pihak pembekal perkhidmatan tersebut akan memaparkan akad tersebut di hadapan skrin dan pembayar zakat boleh membaca akad tersebut dan ia diterima sebagai akad yang sah. Ini bertepatan dengan kaedah fiqh 'tulisan itu dianggap sebagai percakapan di dalam akad's8.

Kaedah pembayaran zakat pada masa kini membuktikan bahawa Islam adalah agama yang meraikan perubahan selaras dengan perkembangan sektor kewangan serta kepelbagaian jenis transaksi pada masa kini daripada bentuk tunai kepada atas talian. Dalam konteks maqūșid hifž al-dīn, ia dapat memudahkan pengurusan kutipan zakat pendapatan. Kaedah tersebut dianggap sebagai inovasi dalam pelaksanaan ibadah zakat supaya agama tidak dilihat statik dan beku.

Kepelbagaian kaedah pembayaran zakat pada masa kini, ia dapat mengelakkan pembayar dari terlepas melakukan kewajipan berzakat dan tidak cuai dalam menunaikan tanggungjawab dalam agama bagi membantu golongan yang memerlukan. Pembayaran

56 'Abd al-Raḥmān bin Muhammad 'Awd al-Jazirī, Kitāb al-Fiqh 'alā al-Madhāhib al-Arba 'ah (Bayrūt: Dār al-Ihyyā' al-Turāth al-'Arabī, t.t.), 1:516.; al-Zuhaylī, al-Fiqh al-Islāmī, 2:750.

57 Abū Ishaq al-Syīrazī, al-Muhadhdhab (Bayrūt: Dār al-Kutub al'Ilmiyyah, 1995), 1: 751.

58 Muhammad 'Uthmān Syibīr, al-Qawā'id al-Kulliyyah wa alDawābit al-Fiqhiyyah fì al-Syarī'ah al-Islāmiyyah (Urdun: Dār alNafā'is, 2007), 255.; Muhammad al-Zarqa', Syarh al-Qawā 'id alFiqhiyyah (Damsyiq: Dār al-Qalam, 1998), 2:349.; 'Alī Muḥammad Aḥmad Abū al-'Izz, al-Tijārah al-Iliktraniyyah wa Aḥkāmihā fì alFiqh al-Islāmī (Urdun: Dār al-Nafā'is, 2013), 138. 
boleh dibuat pada bila-bila masa dan di mana-mana tanpa terbatas dengan waktu dan tempat tertentu sahaja. Oleh hal yang demikian, ia dapat menyekat mafsadah iaitu sikap melewatkan atau tidak melakukan pembayaran zakat.

\section{KESIMPULAN}

Pengaruh dan kedudukan mazhab Syafii telah menjadi asas di dalam sistem perundangan Islam di Malaysia sejak dahulu lagi sehingga ke masa kini. Pengurusan fatwa di Malaysia juga berkembang sesuai dengan peredaran masa dan perubahan persekitaran. Pembaharuan dalam proses dan prosedur pengeluaran fatwa telah mengubah senario pengeluaran fatwa termasuk fatwa yang berkaitan zakat.

Artikel ini menunjukkan pihak berautoriti telah membuat keputusan fatwa di luar kerangka mazhab Syafii dalam beberapa isu dengan mengambilkira maqasid shariah. Walau bagaimanapun, MJFMK dan Jawatankuasa Fatwa Negeri-negeri di Malaysia masih terikat dengan pandangan mazhab Syafii dalam memutuskan keputusan fatwa-fatwa zakat.

Berdasarkan realiti anjakan dan perubahan sandaran hukum fatwa zakat yang berlaku di Malaysia, terdapat ruang untuk menganalisis fatwa-fatwa zakat dari perspektif maqasid shariah. Dicadangkan penulisan kajian akan datang menganalisis pertimbangan maqasid shariah dalam fatwa-fatwa zakat yang diputuskan oleh pihak-pihak yang berautoriti. Hal ini bertujuan memastikan objektif pensyariatan zakat tercapai dan mașlaḥah manusia benar-benar terjamin serta terpelihara.

\section{BIBLIOGRAFI}

Abdullah Ishak. Islam di Nusantara (Khususnya di Tanah Melayu). Kuala Lumpur: Bahagian Hal Ehwal Islam, Jabatan Perdana Menteri, 1992.

Abī 'Ubayd al-Qāșim bin Sālam. Kitāb al-Amwāl. Bayrūt: Dār al-Fikr, 1988.

Abdul Halim El-Muhammady. Pengaruh Madhhab Shafi ‘ dan 
Masalah Kaum Muda di Malaysia. Kajang: Persatuan Bekas Mahasiswa Islam Timur Tengah, 1982.

Ahmad Hidayat Buang. "Analisis Fatwa-fatwa Syariah di Malaysia." Dalam Fatwa di Malaysia. Kuala Lumpur: Jabatan Syariah dan Undang-undang APIUM, 2004.

Ahmad Rayyan. Khidmat al-Internet. Emirates: Manshurat alMajma‘ al-Thaqafi Abu Zabi, 1997.

'Alī Muḥammad Aḥmad Abū al-'Izz. Al-Tijārah al-Iliktraniyyah wa Ahkāmihā fì al-Fiqh al-Islāmī. Urdun: Dār al-Nafā' is, 2013.

Anisah Ab. Ghani et al. "Penerimaan Masyarakat Islam di Malaysia Terhadap Amalan Percampuran Mazhab Dalam Isu-Isu Mazhab.” Jurnal Fiqh 4 (2007), 198.

Ardit Llazani. "An SMS Client for Mobile Banking" Disertasi M.Sc., Fakulti Sains Komputer \& Teknologi Maklumat, Universiti Malaya, 2003.

Al-Asyqar, "Umar Sulaymān. "Idārah Wālī Māl al-Zakāh aw Mașraf al-'Amilīn 'Alayhā." Dalam Abhāth Qaḍ̄āā alZakāh al-Mu'āṣarah. Cet. ke-3. al-Urdun: Dār al-Nafā'is, 2004.

Al-Bayhaqī, Abī Bakar Aḥmad bin al-Husayn bin 'Alī. alMinnatu al-Kubrā Syarh wa Takhrīj Sunan al-Ṣughrā. Ed. Muḥammad Ḍīā' al-Raḥmān al- 'Aẓmī. Rīyāḍ: Maktabah āl-Rusyd, 2001.

Fatimi. Islam Come to Malaysia. Singapura: Sociology Research Institute, 1963.

Fatwa Negeri Terengganu bagi Tahun 1999. Dicapai 6 Januari 2016. http://mufti.terengganu.gov.my/maxc2020/portal/me dia/38/3b588319aa294496c924006279bc2886.pdf

Gwenael Le Bodic. Mobile Mesaging Technologies and Services: $S M S, E M S$ and $M M S$. New York: John Wiley \& Sons Inc, 2005 .

Hamizul Abdul Hamid. Eksklusif Zakat. Selangor: Galeri Ilmu Sdn. Bhd., 2012. 
Hasnan Kasan. Institusi Fatwa di Malaysia. Selangor: Penerbit Universiti Kebangsaan Malaysia, 2008.

Jabatan Mufti Johor. Fatwa Mufti Kerajaan Johor yang difatwakan oleh Dato' Syed Alwi bin Tohir al-Haddad. Cet. ke-3. Johor: Bahagian Penerbitan Jabatan Agama Johor, 1981.

Jabatan Perdana Menteri. Buku Fatwa-fatwa Mufti Wilayah Persekutuan 1987-2010.

Al-Jazirī, 'Abd al-Raḥmān bin Muḥammad 'Awd. Kitāb al-Fiqh 'alā al-Madhāhib al-Arba'ah. Bayrūt: Dār al-Iḥyā' alTurāth al-'Arabī, t.t.

John Crawfurd. History of the Indian Archipelago. London: Frank Cass and Co. Ltd., 1877.

Al-Kasānī, 'Alā' al-Dīn Abī Bakr bin Mas'ūd al-Hanāfĩ. Badā' 'i ' al-Șana' $i$ '. Cet. ke-2. Bayrūt: Dār al-Kutub al-'Ilmiyyah 2003.

Keputusan Fatwa Negeri Terengganu bagi Tahun 1999. Dicapai 6 Januari 2016, http://mufti.terengganu.gov.my/maxc2020/ portal/media/38/3b588319aa294496c924006279bc2886. pdf

Luqman Abdullah. "Kedudukan Mazhab Syafi'i dalam Fatwafatwa Zakat di Malaysia: Sorotan Fatwa Muzakarah Jawatankuasa Fatwa Majlis Kebangsaan dari Tahun 20002010" Makalah, Seminar Isu-isu Kontemporari Dalam Mazhab Shafi'i, Pusat Penyelidikan Mazhab Shafi'i, Universiti Islam Sultan Sharif Ali (UNISSA) (Brunei, 2013), 139-155.

dan Nina Jihatea. "Bermazhab dan Fanatik Mazhab: Satu Sorotan dalam Kerangka Amalan Bermazhab Syafi'i Masyarakat Melayu”. Jurnal Fiqh 4 (2007).

Muhammad Fakhruddin Ishak. "Kesan Teknologi Moden Terhadap Perubahan Hukum: Analisis Terhadap Penggunaan Short Message Service (SMS)" Disertasi Sarjana, Kuala Lumpur: Akademi Pengajian Islam, Universiti Malaya, 2010.

Muḥammad Kamāl 'Ațiyyah. Hāal al-Tațbiqiyyah fì Muhāsabāt 
al-Zakāh: Perakaunan Zakat Teori dan Praktis. Terj. Muhammad Kamal 'Atiyyah. Kuala Lumpur: Dewan Bahasa dan Pustaka, 1995.

Muhammad Ikhlas Rosele, Luqman Abdullah, Paizah Hj Ismail dan Mohd Anuar Ramli. "Konflik Fatwa Di Malaysia: Satu Kajian Awal." Jurnal Fiqh 10 (2013), 40.

Muhammad 'Uthmān Syibīr. Al-Qawā'id al-Kulliyyah wa alDawābit al-Fiqhiyyah fì al-Syarī'ah al-Islāmiyyah. Urdun: Dār al-Nafā'is, 2007.

Muḥammad al-Zarqa'. Syarh al-Qawā 'id al-Fiqhiyyah. Damsyiq: Dār al-Qalam, 1998.

Mujaini Tarimin. "Pelaksanaan Zakat Pendapatan dan Permasalahannya." Dalam Zakat: Menuju Pengurusan Profesional. Kuala Lumpur: Utusan Publications \& Distributors Sdn Bhd, 2005.

Noor Naemah Abd. Rahman. "Amalan Fatwa di Malaysia: Antara Keterikatan Mazhab dan Keperluan Tarjih.” Jurnal Fiqh 4 (2007), 85-86.

Noor Naemah Abd. Rahman. "Ruang Ijtihad dalam Amalan Fatwa di Malaysia: Sorotan dari Sudut Pentadbiran Fatwa," Jurnal Syariah 10, no.2 (2002), 19-30.

Omar Awang. "The Major Arabic Sources Which Determined the Structure of Islamic Thought in the Malay Archipelago Before the Nineteenth Century A.D. in the Field of Law, Theology and Sufism." Dalam Islamika, ed. Lutpi Ibrahim. Kuala Lumpur: Sarjana Enterprise, 1981.

Othman Ishak. Fatwa dalam Perundangan Islam. Kuala Lumpur: Penerbit Fajar Bakti Sdn. Bhd., 1981.

Portal Rasmi Fatwa Malaysia, e-Fatwa JAKIM. Dicapai 6 Januari 2016, http://www.e-fatwa.gov.my/kategori-fatwa/ zakat?page $=5$

Portal Rasmi Fatwa Malaysia, e-Fatwa JAKIM. Dicapai 6 Januari 2016, http://www.e-fatwa.gov.my/kategori-fatwa/ zakat?page $=5$ 
Portal Rasmi Fatwa Malaysia, e-Fatwa JAKIM. Dicapai 23 Januari 2016, http://www.e-fatwa.gov.my/fatwa-negeri/ fatwa-tentang-zakat-pendapatan.

Portal Rasmi Fatwa Malaysia, e-Fatwa JAKIM. Dicapai 6 Januari 2016, http://www.e-fatwa.gov.my/fatwa-negeri/fatwa-mengenai-bayaran-zakat-gaji-bulanan-yang-dibuat-oleh-majikan-dengan-izin-atau-per

S.Q. Fatimi. Islam Come to Malaysia. Singapura: Sociology Research Institute, 1963.

Suryani Masnan. "Kaedah Pembayaran Zakat Pendapatan Melalui Skim Potongan Gaji oleh Lembaga Zakat Selangor" Disertasi Sarjana, Jabatan Fiqh dan Usul, Akademi Pengajian Islam, Universiti Malaya, 2012.

. "Kaedah Taksiran Zakat Pendapatan Menurut al-Qaradawi: Kajian Perbandingan dengan Skim Potongan Gaji (SPG)." Dalam Pengurusan Zakat Kontemporari. Melaka: IKaZ UiTM Melaka, 2013.

Syahațah, Husayn. al-Tațbiq al-Mu'āṣir li al-Zakāh wa Kayfa Tahsib Zakāh Mālik. Mișr: Dār al-Nasyr li al-Jāmi'at, 2000.

Al-Syīrazī, Abū Isḥaq. Al-Muhadhdhab. Bayrūt: Dār al-Kutub al'Ilmiyyah, 1995.

T.W. Arnold. The Preaching of Islam. London: t.p., 1913.

Ummi Farahin Yasin, Noor Naemah Abdul Rahman dan Mohd Faez Mohd Shah. "Pengambilkiraan Realiti Semasa dalam Berfatwa: Analisis Terhadap Fatwa Zakat di Selangor". Jurnal Fiqh 10 (2013).

Wan Zulkifli Wan Hassan. "Pengaruh Mazhab Syafie dalam Fatwa Mengenai Zakat di Terengganu: Kajian dari Tahun 1953 2005." Tesis kedoktoran, Jabatan Fiqh dan Usul, Akademi Pengajian Islam, Universiti Malaya, 2008.

Al-Zuhaylī, Wahbah. al-Fiqh al- Islāmī wa Adillatuh. Cet. ke-2. Dimasyq: Dār al-Fikr, 1985. 
Jurnal Fiqh, No. 13 (2016) 57-88 